\title{
DOES THE USE OF DYNAMIC SURGICAL GUIDANCE ASSIST ACCURATE PEDICLE SCREW PLACEMENT IN PATIENTS WITH OSTEOPOROSIS OR OSTEOPENIA?
}

\author{
O USO DO GUIA CIRÚRGICO DINÂMICO AUXILIA A ACURÁCIA DO POSICIONAMENTO DOS \\ PARAFUSOS PEDICULARES EM PACIENTES COM OSTEOPOROSE OU OSTEOPENIA?
}

\section{¿EL USO DE GUÍA QUIRÚRGICA DINÁMICA AYUDA A COLOCAR CON PRECISIÓN LOS TORNILLOS PEDICULARES EN PACIENTES CON OSTEOPOROSIS U OSTEOPENIA?}

\author{
Helton L A Defino, ${ }^{1}$ John Williams, ${ }^{2}$ Georgia-Lea Williams, ${ }^{3}$ Keri George, ${ }^{4}$ Randal Betz, ${ }^{5}$ David Powell, ${ }^{6}$ John Gaughan, ${ }^{7}$ Maurice Bourlion, ${ }^{8}$ \\ 1. Ribeirão Preto Medical School, University of São Paulo, Ribeirão Preto, São Paulo, Brazil \\ 2. Orthopedic North East, Fort Wayne, Indiana, USA \\ 3. Wheaton University, Wheaton, Illinois, USA \\ 4. SpineGuard Inc - San Francisco, CA, United States \\ 5. Institute for Spine \& Scoliosis, Lawrenceville, New Jersey USA \\ 6. FW Radiology, Fort Wayne, Indiana, USA \\ 7. Temple University School of Medicine, Philadelphia, Pennsylvania USA \\ 8. Jean Monnet University, Saint-Etienne, France
}

\begin{abstract}
Objective: To compare the use of a dynamic surgical guide (PediGuard ${ }^{\circledR}$ ) and pilot hole preparation, with the use of a probe and the aid of fluoroscopy in osteoporotic or osteopenic patients undergoing pedicular fixation of the thoracic or lumbar spine. Methods: One hundred and eight patients were randomized. A pilot hole was prepared with the dynamic surgical guide (PediGuard ${ }^{\circledR}$ ), or with a probe with the aid of fluoroscopy. A total of 657 vertebral pedicles (120 thoracic and 180 lumbar) were included in the study. The parameters used for the comparison were: accuracy of the pedicular screw, number of fluoroscopic shots, and change in intraoperative trajectory of the perforation after detecting pedicle wall rupture. Results: In the group with use of the dynamic surgical guide, malpositioning of the pedicle screws was observed in $8(2.6 \%)$ patients and intraoperative change of perforation trajectory in 12 (4\%) patients, and there were 52 fluoroscopic shots. In the group without use of the dynamic surgical guide (PediGuard ${ }^{\circledR}$ ), misplacement of the pedicle screws was observed in $33(11 \%)$ patients and intraoperative change of perforation trajectory in $47(13.2 \%)$ patients, and there were 136 fluoroscopic shots. Conclusion: The use of the dynamic surgical guide (PediGuard ${ }^{\circledR}$ ) in patients with osteoporosis or osteopenia enabled more accurate placement of pedicular screws, with less change in the intraoperative course of the perforation and less intraoperative radiation. Level of Evidence II; Randomized clinical trial of lesser quality.
\end{abstract}

Keywords: Orifice Valves; Fluoroscopy; Bone Diseases, Metabolic; Bone Screws.

\section{RESUMO}

Objetivo: Comparar o uso de um guia cirúrgico dinâmico (PediGuard ${ }^{\circledR}$ ) e o preparo de orifício piloto com uma sonda e o auxílio de fluoroscopia em pacientes com osteopenia ou osteoporose submetidos à fixação pedicular da coluna torácica ou lombar. Métodos: Cento e oito pacientes foram randomizados. Um orifício piloto foi preparado com o guia cirúrgico dinâmico (PediGuard ${ }^{\circledR}$ ) ou com uma sonda com auxílio de fluoroscopia. Foram incluídos no estudo 657 pedículos vertebrais (120 torácicos e 180 lombares). Os parâmetros usados para a comparação foram: acurácia da colocação do parafuso pedicular, número de disparos fluoroscópicos e mudança da trajetória intraoperatória da perfuração depois da detecção de ruptura da parede do pedículo. Resultados: No grupo de pacientes em que se usou o guia cirúrgico dinâmico, observou-se mau posicionamento dos parafusos pediculares em oito $(2,6 \%)$ pacientes e alteração da trajetória intraoperatória da perfuração em 12 (4\%) pacientes, com 52 disparos fluoroscópicos. No grupo de pacientes em que o guia cirúrgico dinâmico (PediGuard ${ }^{\circledR}$ ) não foi usado o mau posicionamento dos parafusos pediculares foi observado em 33 (11\%) pacientes, a mudança intraoperatória da trajetória da perfuração foi vista em 47 (13,2\%) pacientes, com 136 disparos fluoroscópicos. Conclusão: O uso do guia cirúrgico dinâmico (PediGuard ${ }^{\circledR}$ ) em pacientes com osteoporose ou osteopenia permitiu a colocação de parafusos pediculares com maior acurácia, com menor alteração da trajetória intraoperatória da perfuração e menor dose de radiação intraoperatória. Nível de Evidência II; Estudo clínico randomizado de menor qualidade.

Descritores: Válvulas de Orifício; Fluoroscopia; Doenças Ósseas Metabólicas; Parafusos Ósseos.

\section{RESUMEN}

Objetivo: Comparar el uso de una guía quirúrgica dinámica (PediGuard®) y la preparación del orificio piloto con una sonda y la ayuda de fluoroscopia en pacientes con osteopenia u osteoporosis sometidos a fijación pedicular de la columna torácica o lumbar. Métodos: Ciento ocho pacientes fueron asignados aleatoriamente. Se preparó un orificio piloto preparado con la guía quirúrgica dinámica (PediGuard®) o con

Study conducted at the Hospital das Clínicas Ribeirão Preto and Orthopedic North East, Fort Wayne, Indiana, USA.

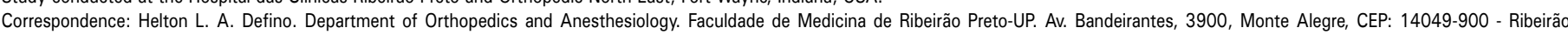
Preto,SP, Brasil. hladefin@fmrp.usp.br 
una sonda con ayuda de fluoroscopia. Se incluyeron en el estudio 657 pedículos vertebrales (120 torácicos y 180 lumbares). Los parámetros utilizados para la comparación fueron: precisión de la colocación del tornillo pedicular, número de disparos del dispositivo de fluoroscopia y cambio en la trayectoria intraoperatoria de la perforación después de la detección de ruptura de la pared del pedículo. Resultados: En el grupo de pacientes en el que se utilizó la guía quirúrgica dinámica, se observó mal posicionamiento de los tornillos pediculares en 8 (2,6\%) pacientes y cambios de la trayectoria intraoperatoria de la perforación en 12 (4\%) pacientes, con 52 disparos del aparato de fluoroscopia. En el grupo de pacientes en los que no se utilizó la guía quirúrgica dinámica (PediGuard®), se observó un mal posicionamiento de los tornillos pediculares en 33 (11\%) pacientes, el cambio intraoperatorio de la trayectoria de perforación se observó en 47 (13,2\%) pacientes, con 136 disparos fluoroscópicos. Conclusión: El uso de la guía quirúrgica dinámica (PediGuard®) en pacientes con osteoporosis u osteopenia permitió la colocación de tornillos pediculares con mayor precisión, menos cambios en la trayectoria intraoperatoria de la perforación y dosis más baja de radiación intraoperatoria. Nivel de Evidencia II; Ensayo clínico aleatorizado de menor calidad.

Descriptores: Válvulas de Orificio; Fluoroscopía; Enfermedades Óseas Metabólicas; Tornillos Óseos.

\section{INTRODUCTION}

Pedicle screw fixation is widely used in the thoracic and lumbar spine to enhance arthrodesis and to correct deformities. The clinical usefulness of pedicle screw fixation is supported by the high rate of fusion, deformity correction, and clinical outcomes. ${ }^{1,2}$

Some drawbacks of pedicle screw fixation are the potential for inaccurate screw placement and the exposure of the surgeon, patient, and operating room personnel to radiation. ${ }^{3,4}$

The average accuracy for pedicle screws inserted freehand or with fluoroscopy is $85.1 \%$ and for pedicle screws using navigation, $95.5 \%{ }^{5}$ Fluoroscopy is the most common technique used to assist pedicle screw insertion due to its capacity to present real time images and produce a higher rate of accurate screw placement than with the freehand technique., ${ }^{5,6}$ However, the surgeon's exposure to radiation during a fluoroscopic assisted thoracolumbar pedicle screw surgery is 10-12 times greater compared to other non-spinal procedures assisted by the fluoroscopic technique. ${ }^{6,7}$

Improved instrumentation, as well as novel image-guided and navigation techniques, were developed to improve pedicle screw placement and accuracy. A pedicle probe was developed, called

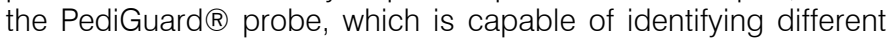
tissue types by measuring electrical conductivity. The aim of the PediGuard $\AA$ probe was to improve pedicle screw accuracy and reduce the surgeon's exposure to radiation. (Figure 1) A change in the pitch and cadence of the audio feedback indicates a change in the tissue around the tip of the PediGuard ${ }^{\circledR}$ probe. A mid-range pitch and medium cadence audio signal can be heard as the probe is advanced through cancellous bone. A low pitch and low cadence audio signal can be heard as the probe approaches the pedicle cortical wall, and is the first indication of a potential pedicle breach. ${ }^{8-10}$

The ability of Dynamic Surgical Guidance-DSG (PediGuard $\mathbb{}$ ) probe) to improve pedicle screw accuracy and reduce radiation exposure has been shown in vitro using human cadaver specimens, as well as in clinical trials. ${ }^{11-13}$ However, bone mineral density was not considered in these studies. Experimental studies have suggested that bone electrical and dielectric properties depend on the bone density. ${ }^{14,15}$ The PediGuard $\AA$ probe emits an electrical current that flows through the tissue, from the inner electrode to the outer electrode, creating a circular electromagnetic detection field at the tip of the instrument. This study was motivated by the lack of studies using the PediGuard $\AA$ probe in osteopenic or osteoporotic bone, and by reports that bone electrical and dielectric properties depend on bone mineral density. ${ }^{14-16}$ Study of this topic is imperative, because osteoporosis effects over one in three women and one in five men aged over fifty, worldwide. ${ }^{17}$ It is a huge problem that often leads to spinal degeneration and deformity; ${ }^{17}$ therefore, it is very important to have a safe and accurate way to insert pedicle screws in these patients.

The aim of the study was to determine the relative effectiveness

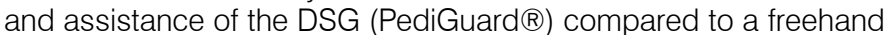
technique assisted by lateral fluoroscopy in the preparation of the pilot holes for placement of pedicle screws in patients with osteopenia or osteoporosis. The hypothesis of the study was that the use of the DSG to prepare the pilot hole in osteoporotic and osteopenic patients improves the accuracy of pedicle screw insertion, reduces the number of breaches in vertebral pedicles, and decreases intraoperative radiation.

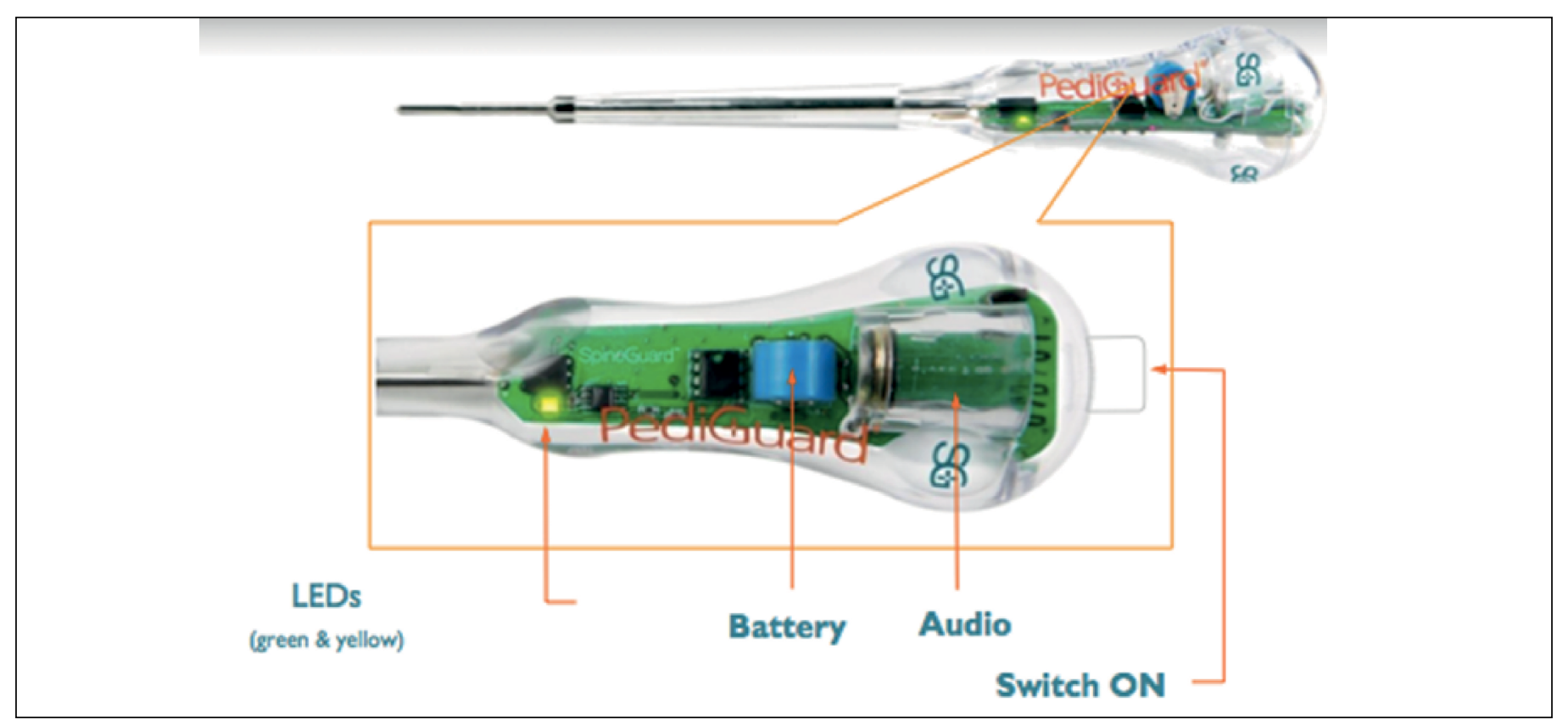

Figure 1. Dynamic surgical guide device - PediGuard ${ }^{\circledR}$ probe. 


\section{METHODS}

The study was approved by local IRB. The study was designed to analyze the potential of the DSG (PediGuard $\AA$ ) device to improve the accuracy of pedicle screw placement and reduce intraoperative radiation. The study was a prospective, randomized study of osteopenic or osteoporotic patients who underwent thoracic and/or lumbar pedicle screw fixation using the DSG (PediGuard $\AA$ ) device or the freehand technique, both assisted by fluoroscopy, for pilot hole preparation.

The inclusion criteria were: Patients undergoing primary surgery with pedicle screw fixation of the spine between T9 and L5, older than 18 years old, osteopenia or osteoporotic (DEXA scan -1 to -2.5 osteopenia, $\leq 2.5$ + osteoporosis) open surgery, and written informed consent.

The exclusion criteria were: pedicle screw insertion by image navigation techniques, tumors, pregnant women, patients under the age of 18, previous surgery/fused spinal levels, unwillingness to sign the written informed consent and assent, congenital deformity of the spine, and normal BMD.

A total of 108 patients (42 males and 66 females - Table 1) aged between 50 and 87 years undergoing thoracic or lumbar pedicle screw fixation were enrolled in the study. The patients were randomly allocated to two groups, according to the method used to prepare the pilot hole.

A total of 657 pedicles were instrumented and included in the study: 300 pedicles (120 thoracic and 180 lumbar) in the DSG group and 357 pedicles (146 thoracic and 211 lumbar) in the standard technique group $(p=0.0216)$. The distribution of the instrumented level across the two groups is shown in Table 2.

All patients were osteoporotic or osteopenic according to DXA evaluation ( -1 to $2.5=$ osteopenia and $\leq 2.5=$ osteoporosis). Osteoporosis was observed in 97 patients and osteopenia in 11 patients.

In both groups, the entry point was assessed using an awl and by a lateral fluoroscopy. In the DSG group, the pilot hole was prepared using PediGuard $₫$ device and in the standard group, the pilot hole was prepared using a blunt probe. After preparation of the pilot hole, tapping was performed, the pedicle wall was checked with a blunt small probe, and the screws were inserted.

The parameters used to compare both groups were the number of fluoroscopy shots, screw accuracy, and change of intraoperative trajectory after confirming a palpated breach on the pedicle wall.

The number of fluoroscopy shots was recorded for each screw inserted, from the assessment of the entry point through to the final screw placement.

The accuracy of screw placement was assessed using a low dose post-operative CT, which was evaluated by an independent

Table1. Distribution of patients by age.

\begin{tabular}{c|c|c|c}
\hline Female (age) & No. & Male (age) & No. \\
\hline $50-65$ & 21 & $50-65$ & 15 \\
\hline $66-80$ & 39 & $66-80$ & 24 \\
\hline $81-87$ & 6 & $81-87$ & 3 \\
\hline Total & 66 & & 42 \\
\hline
\end{tabular}

Table 2. Distribution of the instrumented pedicle.

\begin{tabular}{c|c|c}
\hline Level & Dynamic Surgical Guidance & Standard Technique \\
\hline T9 & 24 & 22 \\
\hline T10 & 26 & 34 \\
\hline T11 & 32 & 40 \\
\hline T12 & 38 & 50 \\
\hline L1 & 40 & 52 \\
\hline L2 & 38 & 50 \\
\hline L3 & 36 & 40 \\
\hline L4 & 34 & 37 \\
\hline L5 & 32 & 32 \\
\hline Total & 300 & 357
\end{tabular}

senior radiologist (DP). For this study, pedicle screws were considered "in" ( $<2 \mathrm{~mm}$ of pedicle cortical breach) or "out" ( $\geq 2 \mathrm{~mm}$ of cortical pedicle breach).

Statistical analysis was performed using Fisher's exact test, to compare the number of fluoro shots, screw reposition, screw accuracy, and change of intraoperative trajectory after a confirmed palpated breach. A p value less than 0.05 was considered significant.

\section{RESULTS}

Accurate pedicle screw placement remains a critical issue in spine surgery. To evaluate the impact of the DSG probe on pedicle screw accuracy, we used low dose postoperative CT. The number of pedicle breaches was $8(2.6 \%)$ misplaced screws out of 300 in the DSG group and $33(11 \%)$ out of 357 in the freehand group. (Figure 2) The number of misplaced pedicle screws was significantly higher in the freehand group than in the DSG group (Fisher's exact test, $p<0.001$ ).

Once the pilot hole is made, the hole can be palpated with a ball-tipped feeler to detect breaches of the pedicle wall. Once a breach is intraoperatively detected, the pilot hole can be changed. Change of intraoperative trajectory after confirmed palpated breach was observed in 12 (4.0\%) perforations in the DSG group and 47 $(13.2 \%)$ in the freehand group. The rate of change of intraoperative trajectory was significantly higher in the freehand group (Fisher's exact test, $p<0.001$ ). (Figure 3)

Radiation exposure in spinal surgery is a growing concern. To compare radiation exposure between the DSG and freehand technique groups, the number of fluoro shots during pedicle screw placement was recorded. A total of 52 shots were recorded in the DSG group, and 136 shots in the freehand group. (Figure 4) The number of fluoro shots was significantly higher in the freehand group than the DSG group (Fisher's exact test $p<0.0001$ ). The use of DSG can reduce the radiation exposure during pedicle screw insertion in osteopenic or osteoporotic bone.

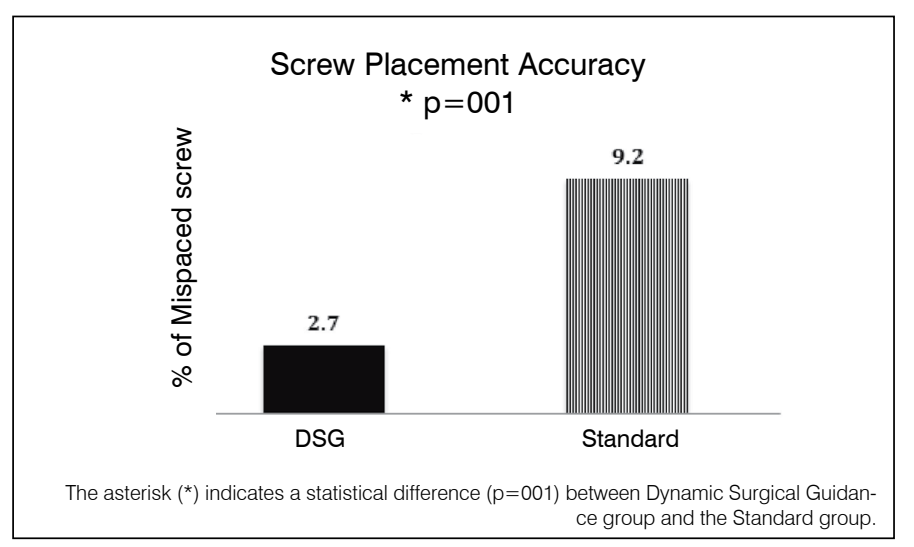

Figure 2. Screw placement accuracy.

\section{Change of preparation trajectory ${ }^{*} p=0.0001$}

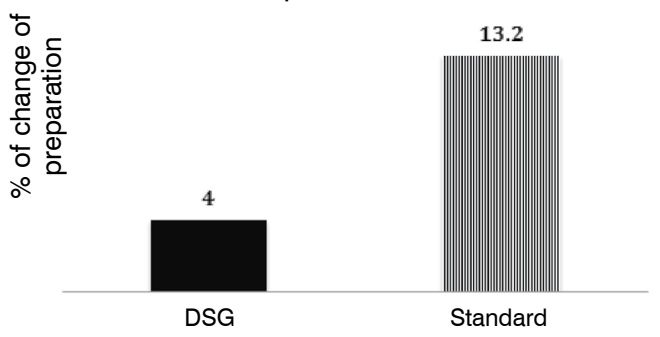

The asterisk $\left(^{\star}\right)$ indicates a statistical difference $(p<0.0001)$ between the Dynamic Surgical Guidance (DSG) group and the Standard group.

Figure 3. Change of preparation trajectory. 


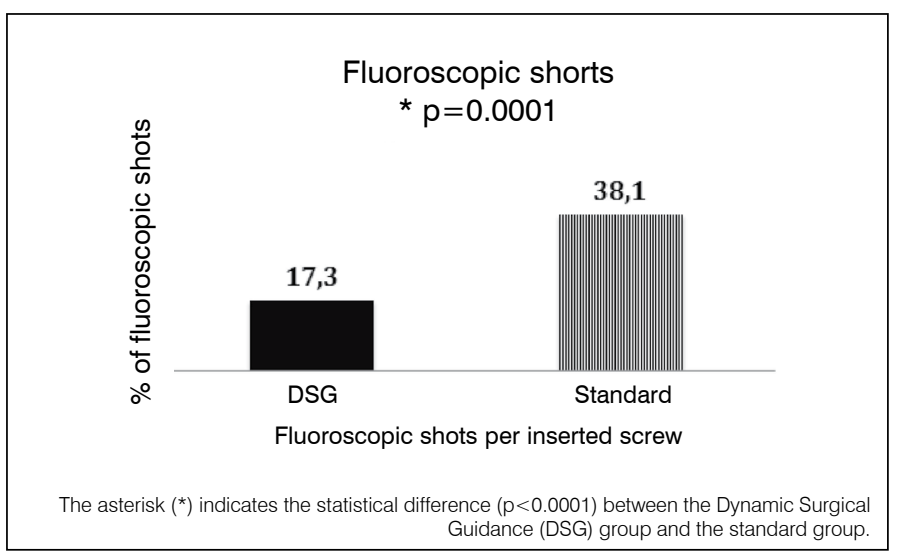

Figure 4. The graph illustrates the percentage of fluoroscopic shots per inserted screw.

\section{DISCUSSION}

The use of the DSD device to prepare pedicle pilot holes in osteoporotic and osteopenic patients undergoing pedicle screw fixation in the thoracic and lumbar spine improved the accuracy of pedicle screw placement, decreased the change of intra-operative pilot hole trajectory, and decreased the use of intra-operative radiation.

The role of the DSG device in improving pedicle screw accuracy and reducing intraoperative radiation has been observed in experimental and clinical studies, but none of them were performed in osteopenic or osteoporotic bones. ${ }^{8-12}$ Although there are several technologies that assist with pedicle navigation, the DSG device is the only hand-held device that can detect possible vertebral cortex perforation during pedicle preparation for screw placement. The probe of the DSG device emits an electrical current which flows from the inner electrode to the outer electrode, creating a circular electromagnetic detection field at the tip of the instrument. 9,10 The device provides real time visual and audio cues for the surgeon, as an effect of the electrical conductivity in the tissues. In cortical bone the DSG device provides a low pitch sound and slow cadence, while in cancellous bone it produces a medium pitch and medium cadence, and a high pitch and rapid cadence are emitted when the device tip contacts blood or soft tissue. When the tip of the DSG device is against the cortical bone of the pedicle wall or the vertebral cortex, the sound changes significantly. This anticipation mode of the DSG device occurs before the probe actually breaches the cortex. ${ }^{9,10}$

The impedance measurement capability at the tip of the probe is the fundamental mechanism of the DSG device as the instrument passes through the cancellous bone of the pedicle. The electrical properties of the tissue are influenced by environmental conditions ( $\mathrm{pH}$, moisture content, temperature) and biological variables such as microstructure and chemical bone composition. ${ }^{16-21}$ The microstructure of osteoporotic and osteopenic bone is different from that of normal bone. These microstructural changes influence the electrical properties of bone. ${ }^{14-16}$ However, in the range of osteoporotic and osteopenic values of the patients included in this study, there was no interference with the impedance properties of the vertebral bone. Bone electrical and dielectric properties depend on the bone density, and are frequency-dependent. Impedance is lowest in the longitudinal direction and highest in the radial direction. ${ }^{17,18}$ However, the limit of the degree of osteoporosis that still allows characterization of cancellous bone by means of bone tissue impedance is not yet established.
The importance of accuracy of pedicle screw insertion is well established in the field of spinal surgery. Perforation of the pedicle wall can lead to complications such as dural tear, nerve root injury, paraplegia, or vascular injury; although in many instances, a misplaced screw does not result in these complications. ${ }^{19,20}$ The importance of pedicle screw accuracy is well recognized; however, there is currently no gold standard method for accessing it. ${ }^{21,22}$

Perforations less than $2 \mathrm{~mm}$ on CT scan are thought not to be associated with clinical outcome. Other authors report perforations as large as $4 \mathrm{~mm}$ being associated with no problems. ${ }^{21,22}$ They report an incidence of medial cortical penetration up to $8 \mathrm{~mm}$, with two minor neurological injuries. They hypothesize a 4-mm safe zone, which includes $2 \mathrm{~mm}$ of epidural space and $2 \mathrm{~mm}$ of subarachnoid space. Belmont et al. ${ }^{23}$ considered screw penetration of the medial pedicle wall less than or equal to $2 \mathrm{~mm}$ to be acceptable. We considered 2 $\mathrm{mm}$ or less of screw perforation to be acceptable in this study.

The method that we used to evaluate the breach was based on the accepted literature concept that any breach less than $2 \mathrm{~mm}$ of the pedicle is safe. ${ }^{24,25}$ However, the location of the breach was not considered in our study. The location of the breach should be considered to determine the safety of the screw placement, but this was not included in the goals of our study.

In the thoracic spine, pedicle anatomy is more complex and pedicle size is smaller, resulting in a more challenging screw placement. The difference in accuracy of pedicle screw placement in the thoracic and lumbar spine were not considered in our study, and only lower thoracic pedicle screw placements (below vertebra T9) were included in the study. As thoracic screws are generally more technically challenging, a higher rate of malpositioned pedicle screws would be expected.

The goal of our study was to evaluate and compare the accuracy of pedicle screw placement between the standard and DSG device techniques, without any detailed grading system that could evaluate the amount, location, and corresponding clinical symptoms.

The insertion of pedicle screws assisted by fluoroscopy exposes the surgeon to significant levels of radiation compared to other non-spinal musculoskeletal procedures, with up 10-12 times higher rates of radiation exposure. ${ }^{24,25}$ The reduction of radiation exposure has been strongly recommended, and it can be achieved by reduced exposure time, increased distance from the beam, increased shield with gown, thyroid gland cover, and glasses and beam collimation. ${ }^{25}$ DSG allowed the surgeon to reduce the radiation exposure while maintaining safe pedicle screw placement. The reduction of radiation exposure for the surgeon that we observed in osteoporotic or osteopenic patients was also observed in patients with normal BMD using DSG to prepare pedicle pilot holes. ${ }^{6,7} \mathrm{How}$ ever, a potential bias of our study, as also mentioned in the study of Chapud et al., ${ }^{6}$ was the user's dependence on fluoro, i.e. the surgeon may have been unintentionally biased to use more fluoro when not using DSG.

The results of the study has shown that the use of the DSG device to prepare pilot holes for pedicle screw insertion in the thoracic and lumbar spine of osteopenic and osteoporotic patients improves pedicle screw accuracy and reduces intraoperative radiation, compared to the freehand technique. The real-time detection of vertebral cortical breaches provided by DSG also worked in osteoporotic and osteopenic bone, and increased pedicle screw accuracy in the thoracic and lumbar spine, compared to the standard, freehand technique.

All authors declare no potential conflict of interest related to this article.

CONTRIBUTION OF THE AUTHORS: Each author contributed individually and significantly to the development of the manuscript. HLAD Substantial contribution to the conception or design of the work, or acquisition, analysis or interpretation of the data for the work; JW, GLW, KG, RB, DP, JG, MB Actively participate in the discussion of results; RB Writing of the work or critical review of its intellectual content; HLAD, JW, GLW, KG Review and approval of the final version of the manuscript. 


\section{REFERENCES}

1. Boos N, Webb JK. Pedicle screw fixation in spinal disorders: a European view. Eur Spine J. 1997:6(1):2-18.

2. Yahiro MA. Comprehensive literature review. Pedicle screw fixation devices. Spine (Phila Pa 1976). 1994;19(20 Suppl):2274S-8S

3. Aoude AA, Fortin M, Figueiredo R, Jarzem P, Ouellet J, Weber MH. Methods to determine pedicle screw placement accuracy in spine surgery: a systematic review. Eur Spine J. 2015;24(5):990-1004.

4. Tian NF, Huang QS, Zhou P, Zhou Y, Wu RK, Lou Y, et al. Pedicle screw insertion accuracy with different assisted methods: a systematic review and meta-analysis of comparative studies. Eur Spine J. 2011;20(6):846-59.

5. Mason A, Paulsen R, Babuska JM, Rajpal S, Burneikiene S, Nelson EL, et al. The accuracy of pedicle screw placement using intraoperative image guidance systems: a systematic review. J Neurosurg Spine. 2014; 20(2): 196-203.

6. Chaput CD, George K, Samdani AF, Williams JI, Gaughan J, Betz RR. Reduction in radiation (fluoroscopy) while maintaining safe placement of pedicle screws during lumbar spine fusion. Spine (Phila Pa 1976). 2012;37(21):E1305-9.

7. Yu E, Khan SN. Does less invasive spine surgery result in increased radiation exposure? A systematic review. Clin Orthop Relat Res. 2014;472(6):1738-48.

8. Bolger $C$, Wigfield $C$. Image-guided surgery: applications to the cervical and thoracic spine and a review of the first 120 procedures. J Neurosurg. 2000;92(2 Suppl):175-80.

9. Bolger C, Carozzo C, Roger T, McEvoy L, Nagaria J, Vanacker G, et al. A preliminary study of reliability of impedance measurement to detect iatrogenic initial pedicle perforation (in the porcine model). Eur Spine J. 2006:15(3):316-20.

10. Bolger C, Kelleher MO, McEvoy L, Brayda-Bruno M, Kaelin A, Lazennec JY, et al. Electrica conductivity measurement: a new technique to detect iatrogenic initial pedicle perforation. Eur Spine J. 2007:16(11):1919-24.

11. Guillen PT, Knopper RG, Kroger J, Wycliffe ND, Danisa OA, Cheng WK. Independent asses sment of a new pedicle probe and its ability to detect pedicle breach: a cadaveric study. $J$ Neurosurg Spine. 2014;21(5):821-5.

12. Williams J, SamdaniA, Defino HLA, George K, Gaughan J, Betz R. Antecipation of vertebral pedicle breach through dynamic surgical guidance. Coluna/Columna. 2014;13(3):210-3.

13. Bolger C, Brayda-Bruno M, Kaelin A, Kaelin A, Lazennec JY, Le Huec JC, et al. A new device to detect iatrogenic initial vertebral cortex perforation: first clinical results [abstract]. Eur Spine J. 2003;12(Suppl 1):1-79.
14. Ovadia D, Korn A, Fishkin M, Steinberg DM, Wientroub S, Ofiram E. The contribution of an electronic conductivity device to the safety of pedicle screw insertion in scoliosis surgery. Spine (Phila Pa 1976). 2011;36(20):E1314-21

15. Sierpowska J, Töyräs J, Hakulinen MA, Saarakkala S, Jurvelin JS, Lappalainen R. Electrical and dielectric properties of bovine trabecular bone--relationships with mechanical properties and mineral density. Phys Med Biol. 2003:48(6):775-86

16. Sierpowska J, Hakulinen MA, Töyräs J, Day JS, Weinans H, Kiviranta I, et al. Interrelationships between electrical properties and microstructure of human trabecular bone. Phys Med Biol. 2006:51(20):5289-303.

17. Melton LJ 3rd, Atkinson EJ, O'Connor MK, O'Fallon WM, Riggs BL.Bone density and fracture risk in men. J Bone Miner Res. 1998;13(12):1915-23.

18. Sierpowska J, Lammi MJ, Hakulinen MA Jurvelin JS, Lappalainen R, Töyräs J. Effect of human trabecular bone composition on its electrical properties. Med Eng Phys 2007:29(8):845-52.

19. Borcek AO, Suner HI, Emmez H, Kaymaz M, Aykol S, Pasaoglu A. Accuracy of pedicle screw placement in thoracolumbar spine with conventional open technique. Turk Neurosurg. 2014;24(3):398-402

20. Tang J, Zhu Z, Sui T, Kong D, Cao X. Position and complications of pedicle screw insertion with or without image-navigation techniques in the thoracolumbar spine: a meta-analysis of comparative studies. J Biomed Res. 2014;28(3):228-39.

21. Gelalis ID, Paschos NK, Pakos EE, Politis AN, Arnaoutoglou CM, Karageorgos AC, et al. Accuracy of pedicle screw placement: a systematic review of prospective in vivo studies comparing free hand, fluoroscopy guidance and navigation techniques. Eur Spine $\mathrm{J}$ 2012;21(2):247-55.

22. Gertzbein SD, Robbins SE. Accuracy of pedicular screw placement in vivo. Spine (Phila Pa 1976). 1990;15(1):11-4.

23. Belmont PJ Jr, Klemme WR, Robinson M, Polly DW Jr. Accuracy of thoracic pedicle screws in patients with and without coronal plane spinal deformities. Spine (Phila Pa 1976). 2002;27(14):1558-66.

24. Dibra F. Intraopearative image: radiation safety, techniques and technology. In: Wang MY Handbook of minimally invasive and percutaneous spine surgery. Missouri: OMP: 2011:1-10.

25. Jones DP, Robertson PA, Lunt B, Jackson SA. Radiation exposure during fluoroscopically assisted pedicle screw insertion in the lumbar spine. Spine (Phila Pa 1976) 2000;25(12):1538-41 